\title{
Implications of Zakat Management on Improving the Welfare of The Poor \\ (Case Study on Indonesian National Zakat Agency (BAZNAS) Gorontalo City)
}

\author{
Hamdan Ladiku $^{1 *} \quad$ Nur Mohamad Kasim ${ }^{2} \quad$ Waliko $^{3}$ \\ 1.State Islamic Institute (IAIN) Sultan Amai, Gorontalo, Indonesia \\ 2.Universitas Negeri Gorontalo, Indonesia \\ 3.State Islamic University (UIN) Prof Saifuddin Zuhri, Purwokerto, Indonesia
}

\begin{abstract}
Poverty is still a problem in Indonesia. Not a few of the Indonesian people are still living below a decent standard of living. In everyday reality, there are still often homeless people and people who cannot meet their basic needs. Poverty becomes a big problem because it impacts the difficulty of accessing education, increasing criminality, and others. A high poverty rate is a form of economic equality. One of the efforts that can be made to create economic equality is through zakat. This study aims to uncover the implications of zakat management at the National Zakat Agency (BAZNAS) Gorontalo city in improving the welfare of the poor. The main problem is described that zakat is a very strategic Islamic Law in alleviating poverty and improving the welfare of the poor. This research is a field study with qualitative descriptive analysis. The approach used is a multidisciplinary approach, namely normative juridical approach, philosophical approach, theological and historical socio approach. The methods used are observation, interview, survey, and documentation. Furthermore, the data obtained is analyzed and displayed deductively and comparatively. The results showed that the implications of zakat management at the National Zakat Agency (BAZNAS) Gorontalo city in improving the welfare of the poor are seen in various innovations rolled out programs that are oriented towards improving the welfare of the poor. Innovation of the program in the form of empowerment of the poor through the utilization of productive zakat distribution, distribution of consumptive zakat, the synergy of zakat management with professional financial institutions, caring for disaster victims, Construction of Livable Houses (MAHAYANI), scholarships for outstanding children and the amaliah ramadhan movement.
\end{abstract}

Keywords: zakat, welfare, the poor

DOI: $10.7176 /$ RHSS/11-14-04

Publication date:July $31^{\text {st }} 2021$

\section{Introduction}

Based on poverty data, the poverty rate in Indonesia is still very high. The number of poverties in 2012 amounted to $28,590.2$ million people and decreased in 2013 to $28,553.9$ million people. In 2014 there was also a decrease in the number of poor people to $27,727.8$ million people, but in 2015 increased. Therefore, there need to be instruments to reduce the amount of poverty. One of the instruments that are believed to reduce poverty is the zakat. (Mubarokah, 2017)

The process of receiving zakat collected through the system and management of professional zakat management, trust, and transparent in addition to being directed towards consumptive assistance for the Mustahik, is also a potential source to be used for financing productive businesses as part of a profound endeavor to improve the welfare of the poor. Historical records show that in the era of companions, the time of the Ummayah, and Abbasids, riel proves that the people's economy grew so rapidly when the potential of zakat of the people was maximized massively. During the leadership of Umar bin Abdul Aziz in a relatively short period of about two years and six months, there were no more groups of poor community requesters because all Muzakki (compulsory zakat) were empowered to issue their zakat, and the management of zakat distribution was not only limited to consumptive distribution but directed at empowering zakat in the creation of a productive economy. This innovative movement must be realized today so that poverty, which is the enemy of Muslims, can be overcome.

Spiritually, zakat activity is actually like an investment in the hereafter, but the essence of zakat in world affairs has tremendous power to build the people's economy in improving the welfare of the poor. Some of the points of thought that underlie this assumption include: (1) There was high population growth and continued to increase. This demographic implication automatically affects the quantitative totality value of zakat, which will increase, of course, measured in terms of the amount of rupiah collected.; (2)

The ability to collect zakat and a large number of zakat givers can be used as an effective instrument to measure the increase in the welfare of Muslims in general and the welfare of the poor in particular.; (3) Empirical indicators are needed to link the increasing level of awareness of the Muslim community in paying 
zakat. Of course, this indicator is related to the increased awareness and practice of fingers through zakat; and (4) The success in improving the quality of the value of zakat and the quantity of Muzakki reflects the effectiveness of zakat management managed by the Amil Zakat Agency.

In other contexts, zakat functions as a source of funds to develop the Islamic economy with mandate management. Zakat is distributed not only to the poor, which is more aimed at consumption (family) interests but ideally, the funds channeled can be used as business capital to improve the economic creativity of the poor. So, the investment side of zakat is much more beneficial than the consumption side of zakat. Zakat is like giving a hook and bait for the economic development of the people, compared to giving fish that are ready to eat for a moment's benefit. Therefore, the optimization of zakat potential needs to be done by identifying zakat objects, socialization of the collection mechanism through zakat collectors (Amil), and the essential thing after zakat has collected the mechanism distributing zakat to zakat recipients. This effectiveness is also related to efficiency in internal management, including the quality and professionalism of Amil Zakat and transparency in zakat management. (Mustafa, 2018)

It must admit that the utilization of zakat is still far from expectations. This reality can be seen from the figure of the economic role of zakat in poverty alleviation. The zakat that had managed so far has not been able to say more in realizing the welfare of the poor. However, it must acknowledge that the role of Gorontalo City BAZNAS in efforts to improve the welfare of the poor cannot be improved when the programs rolled out are dominant in favor of increasing the productive economy for economically vulnerable communities or what we call the poor. (Kaaba, 2018)

The birth of BAZNAS in Gorontalo City can undoubtedly provide a breath of fresh air in terms of overcoming or reducing the poverty rate, and this institution has become a partner of the government to provide counseling and empowerment for the poor. The government's heavy burden can be reduced, breaking the chain of government bureaucracy when distributing aid because Gorontalo City BAZNAS has a team of volunteers who function as distributors or distributors who will go directly to the consumptive field assistance which package in various activities. productive BAZNAS Gorontalo City provides assistance, education, observation, and evaluation of businesses managed by the poor, with the aim that the business sector can run optimally, and the hope is that businesses financed by BAZNAS Gorontalo City can move optimally so that the level of community welfare the poor can increase. (Pedju, 2018) Of course, with the increase in business and welfare, there will be a change in conditions from Mustahiq (beneficiaries) to Muzakki (people who are obliged to pay zakat), and this means that the management and utilization of zakat distribution are effective and right on target.

Therefore, the management of zakat at BAZNAS Gorontalo City has an open opportunity for an effective poverty eradication program. For this reason, zakat needs to be linked to the most relevant verses of the Koran, for example, concerning the doctrine which requires that there is no concentration of wealth and circular circulation around the elite, as well as the hadith of the Prophet, which explains the function of zakat, which is to transfer wealth from the rich to the poor. This also relates to the verse, which commands cooperation in goodness (ta'awun), frees people from slavery (fakkuraqabah), does general good (birr), fixes and repairs something (Ihsan), gives opportunities for poor people to consume. towards the most basic needs (ta'amul), and so on. (Katili, 2018)

Based on the argumentative study above, zakat and the optimization of its management have significant implications for Muzakki, Mustahik, and the Muslim community in general. For Muzakki, zakat means educating the human soul to like to sacrifice and cleansing the soul from the stingy, arrogant, and arrogant nature that usually accompanies the possession of the large and excessive property. For Mustahik, zakat will eliminate envy and prejudice (su'udzan) towards rich people. More than that, zakat can give hope of a change in fate, exceptionally an increase in the welfare of the poor so that the gap between the rich and the poor can remove. Through zakat, there will be equal distribution of income and property ownership among Muslims for the Muslim community. Meanwhile, in a Muslim society, there is no monopoly, but an economic system will be built that emphasizes cooperation and mutual assistance mechanisms.

Furthermore, the implications of zakat management at BAZNAS Gorontalo City to improve the welfare of the poor can be seen in various innovative programs launched by BAZNAS Gorontalo City. Since its establishment until now, BAZNAS Gorontalo City, through a rolled-out program, aims to improve the standard of life and welfare of the poor people of Gorontalo City.

\section{Research Methods}

This research is a field study with qualitative descriptive analysis. Field research can also be considered a broad approach in qualitative research (Moleong, 2012). The approach used is a multidisciplinary approach, namely normative juridical approach, philosophical approach, theological and historical socio approach. The methods used are observation, interview, survey, and documentation. Furthermore, the data obtained is analyzed and displayed deductively and comparatively. 


\section{Literature Review}

At the expense of others. The function of zakat to prevent the accumulation and prevention of exploitation or social conflict ". It needs to be distinguished by sadaqah, a form of charity and intends to be voluntary. According to Hasan (2006), zakat became a formal and compulsory transfer system in the second decade of Islam (622 AD). The amount of zakat is usually set as 2.5 percent of all productive wealth accumulated over a year. Wealth items consider determining the minimum nisab amount that must own before being obliged to pay zakat. Zakat can vary and include gold, silver, and agricultural and livestock products. However, in modern times, business assets, bank accounts, financial assets, and leased buildings are also considered (Hassan, 2010).

Much of the debate about zakat is centered around these two main concepts: Zakatability (the source of wealth calculated to calculate zakat) and Nisab. In the Qur'an, eight categories are listed that can claim the right to zakat, the two most common are the poor and needy. The type of zakat referred to mainly in this case Zakat paper is also known as al-maal. Another related form of zakat, which usually pays to Everyone who can afford it at the end of fasting in the holy month of Ramadan, is Zakat Fitrah. The amount raised used to help more lacking Muslims celebrate Eid al-Fitr and organize iftar. (Hasan, 2015).

The priority problem in optimizing zakat governance found in this study is the lack of information about the needs and development of Mustahik to Muzakki and the low motivation and ability of Mustahik to develop. Improving the quality and capacity of Amil, especially in the field of technology, becomes a priority solution. The results highlight the urgency of increasing the capacity and capability of Amil in the management of technology-based zakat. Zakat institutions need to prepare the transformation of management towards zakat technology as one of the priorities in optimizing the governance of zakat. Qualitative research using analytical network process methods. Ten respondents representing practitioners, academics, associations, and regulators were selected for their expertise in zakat governance. (Widyastuti.et., al, 2021)

Discussions about the role of the Zakat Fund in the provision of social protection have also been examined in the Middle East and North Africa, for example, in Jordan and Sudan. The paper aims to assess the modalities of different zakat in two countries regulated in several forms by the state. The design methodology and approach of the findings are based on academic library reviews, peer-reviewed literature, and reports published by international organizations, and information provided online by the government and the national Zakat Fund. The choice of these countries is further motivated by the availability of literature in English and Arabic. The finding is that the extent to which Zakat can be used to finance social protection measures varies not only in the way of collection and management but also with the geographical and political conditions of the country. In Sudan, Zakat is mandatory and reaches more households proportionally than in Jordan. While the Koran upholds eight categories of zakat recipients, elections in both countries are the discretion of the state Administrator of funds. (Bilo dan Machado, 2018)

Another study on zakat conducted by Ben \& Guerbouj in 2020 aims to test the impact of zakat on economic growth for a sample of Muslim countries. Zakat is a religious obligation on wealth paid annually to the designated beneficiaries. Because it leads to redistribution of revenues and increases aggregate demand, zakat can be a growth factor within the framework of Islam. Dynamic panel data models were used to investigate the role of zakat in economic growth for a sample of eight Muslim countries during the period from 2004 to 2017. The findings provide evidence that zakat can stimulate the growth of the country. Indeed, because zakat funds are directed to increase consumption, investment, or government spending, it will spur economic growth. The authors conclude that more trade openness allows for an increase in the natural gross domestic product (GDP) per capita. This finding provides empirical support that zakat is a driving factor of economic growth within the framework of Islam. (Ben \& Guerrouj, 2020).

\section{Empowerment of Poor People through The Utilization of Productive Zakat distribution}

Constitution number 23 of 2011 states that the empowerment of zakat funds meets the needs of the mustahik. Mustahik consists of eight asnaf: poor, low-grade, amyl, muallaf, riqab, gharim, sabilillah, and ibnssabil. Based on the Law mandate, zakat funds can be distributed on two types of extensive activities: consumptive and productive activities. Consumptive activities are activities in assistance to solve urgent and immediately exhausted problems after the aid uses. At the same time, productive activities are activities intended for productive businesses that are medium-term and long-term. The impact of this productive activity can generally feel even though the Zakat Infaq Sadaqah (ZIS) funds provided have been used up. Furthermore, the empowerment of Zakat Infaq Sadaqah (ZIS) funds such as food, health, and education. If these needs meet, or there are advantages, allocation can allocate for productive business activities through sustainable empowerment programs. (Fadilah, et., al, 2017)

This model is a productive zakat distribution system that BAZNAS called with the help of rolling without interest to the poor. The realization was carried out through economic empowerment training of the people accompanied by the provision of stimulant assistance monitored and evaluated to the poor in Gorontalo City. BAZNAS Gorontalo usually uses a ball pick-up system. By conducting factual verification in all villages, see 
who is eligible for assistance based on predetermined criteria. Therefore, assistance is usually adjusted to the existing conditions following sharia demands and riel needs conditions of prospective recipients of zakat assistance funds. The zakat distribution model is a product distribution system of zakat aimed at improving the economy of the lower and vulnerable communities while also can be used to strengthen capital for small-scale productive businesses for the economic empowerment of the poor, where the majority of them are Muslims. Therefore, BAZNAS Gorontalo city makes an intelligent effort to change the mindset of dhu'afa through training.

The mechanism of activities taken, as explained by Saleha Zakaria, said that since the aid program is rolling, channeled without interest to the poor who have small kiosk businesses, BAZNAS conducts technical training and manage businesses conducted periodically to prospective beneficiaries. The trick is to record the poor people who will get such assistance in every village in Gorontalo City, then the data is verified. If the prospective beneficiaries are declared eligible, then immediately followed up with training for three days before channeling productive business capital assistance. Besides, BAZNAS Gorontalo city, in improving the welfare of the poor, made a breakthrough by developing effective economic programs through training programs for the younger generation of Islam gathered in baznas assisted organizations, namely Youth Youth Lovers Mosque (PRTAJID). This container is expected to change the mindset of youth and adolescents who have tended to have the cost of living in the elderly without ever trying to finance their own lives. That is one reason behind the establishment of a container of youth and youth mosque lovers (PRTAJID) in Gorontalo city under the auspices of BAZNAS. The presence of Youth Lovers Mosque (PRTAJID) can at least pioneer three things, namely prospering the mosque, becoming an entrepreneur, and loving and developing the art that breathes Islam. (Zakaria, 2018)

This phenomenon is all oriented towards improving welfare at the state of outward well-being and ornate on inner health, which in the Islamic perspective is called true welfare. The development of productive zakat distribution management within three years since establishing BAZNAS Gorontalo City in 2017 to 2019 can be seen in the table presented below. Quantitative data shows that over three years, the National Zakat Agency (BAZNAS) Gorontalo city has distributed productive zakat as much as 7 (seven) stages, previously prospective recipients were fostered through education and training for three days on how to start, implement and manage a good and correct business, as stated in the data below.

Table. 1 Distribution of productive zakat in 2017

\begin{tabular}{|c|c|c|c|}
\hline 1 & 7 Oct 17 & Verification and Training Fund for 60 Poor people & $19,970,000$ \\
\hline 2 & 15 Oct 17 & Micro Economy Business Capital Assistance Fund Phase I & $60,000,000$ \\
\hline 3 & 10 Nov 17 & Micro Economy Business Capital Assistance Fund Phase II & $60,000,000$ \\
\hline 4 & 10 Dec 17 & Micro Economy Business Capital Assistance Fund Phase III & $60,000,000$ \\
\hline & & Total Zakat Productive & $199,970,000$ \\
\hline
\end{tabular}

Source: Badan Amil Zakat (BAZNAS) Gorontalo Financial Management Department BAZNAS which has been processed by the author.

Table. 2 Distribution of productive zakat in 2018

\begin{tabular}{|l|r|l|l|}
\hline 1 & 7 Jan 18 & Verification and Training Fund Phase IV & $22,575,000$ \\
\hline 2 & 20 Jan 18 & Micro Economy Business Capital Assistance Fund Phase IV & $60,000,000$ \\
\hline 3 & 8 Feb 18 & Verification and Training Fund Phase V & $22,575,000$ \\
\hline 4 & 18 Feb 18 & Micro Economy Business Capital Assistance Fund Phase V & $60,000,000$ \\
\hline 5 & 11 Mar 18 & Verification and Training Fund Phase VI & $23,325,000$ \\
\hline 6 & 18 Mar 18 & Micro Economy Business Capital Assistance Fund Phase VI & $60,000,000$ \\
\hline 7 & 8 Apr 18 & Verification and Training Fund Phase VII & $21,825,000$ \\
\hline 8 & 19 Apr 18 & Micro Economy Business Capital Assistance Fund Phase VII & $60,000,000$ \\
\hline \multicolumn{3}{|r|}{ Total Zakat Productive } & $\mathbf{3 3 0 . 3 0 0 . 0 0 0}$ \\
\hline
\end{tabular}

Source: Badan Amil Zakat (BAZNAS) Gorontalo Financial Management Department BAZNAS which has been processed by the author.

Table. 3 Distribution of Productive Zakat in 2019

\begin{tabular}{|c|c|l|c|}
\hline 1 & 12 May 19 & Micro-Business Verification \& Training Fund Mixed Stage I & $15,475,000$ \\
\hline 2 & 30 May 19 & Stage mixed business funds I & $37,500,000$ \\
\hline 3 & 01 Jun 19 & Mixed business micro receiver training fund & $2,350,000$ \\
\hline 4 & 23 Jun 19 & Micro-Business Verification \& Training Fund Mixed Stage II & $17,825,000$ \\
\hline \multicolumn{2}{|c|}{ Total Zakat Productive } & $\mathbf{7 3 , 1 5 0 , 0 0 0}$ \\
\hline
\end{tabular}

Source: Badan Amil Zakat (BAZNAS) Gorontalo Financial Management Department BAZNAS which has been processed by the author.

Based on the table above shows that the utilization of zakat by BAZNAS Gorontalo city to be productive zakat is something that becomes a priority. In three years, 2017-2019, zakat funds that have been channeled to use as productive zakat amounted to Rp. 603.420.000 (Six hundred three million four hundred and twenty thousand rupiahs), with details; in 2017, the utilization of productive zakat that has been channeled is in the 
range of Rp. 199,970,000 (One hundred ninety-nine million nine hundred and seventy thousand rupiahs), in 2018 BAZNAS Gorontalo city distributed productive zakat to the poor amounting to Rp. 330,300,000 (Three hundred thirty million three hundred thousand rupiahs), increasing twice more than the previous year. Meanwhile, for 2019 the amount of productive zakat that has been disbursed is Rp. 73,150,000 (Seventy-three million one hundred and fifty thousand rupiahs).

To make the flow of zakat funds effective in mobilizing the economic dynamics of the poor, BAZNAS Gorontalo city does not directly distribute these zakat funds in the form of cash, but rather the number of funds that are purchased daily goods by team BAZNAS and distributed to each prospective recipient, to be sold in small stalls owned by the beneficiaries. Moreover, the Management of BAZNAS Gorontalo City prepares prospective recipients to be ready to manage and develop a good and correct business. Therefore, prospective recipients of funds rolling productive zakat in training first before this productive assistance are handed over.

Mustofa, an academic specializing in Islamic economics, also responded to this issue. According to him, zakat given to the poor will support their economic improvement if consumed in productive activities. The utilization of productive zakat has the concept of careful planning and implementation, such as assessing the causes of poverty, lack of working capital, and lack of employment. With this problem, there needs to be planning that can develop productive zakat. The development of zakat is productive by making zakat funds as business capital, will have an impact on the economic empowerment of its recipients, and the poor can run or finance their lives consistently. With the zakat fund, poor people will get a fixed income, increase business, develop businesses, and set aside their income to save so that the level of welfare can be increased. (Mustofa, 2018)

In this context, BAZNAS Gorontalo city as an organization engaged in the allocation, utilization, and distribution of zakat funds, not only give zakat but they accompany, give direction and training, with the target that zakat that has been channeled by a productive business so that the recipient of zakat obtain a decent income and independent, which eventually the level of welfare of his life will improve. Until now, BAZNAS Gorontalo city has been and is empowering 490 poor people through productive zakat assistance.

According to the Head of Secretary baznas Gorontalo City, "Everyone from the poor who have a small stall trade business, get additional business capital from zakat funds in the form of goods that are ready to be sold worth Rp. 1,000,000. (One million rupiah). The program is rolling. This means that those who have received this assistance will return to BAZNAS Gorontalo city with an Installment system for 12 months without interest. BAZNAS will give those who manage to return on-time appreciation in the form of gifts. After they complete their obligations, they are then evaluated and verified for business development. After the evaluation and verification process is completed, BAZNAS Gorontalo City then disburses additional funds as the second phase of capital worth Rp. 1.500.000. The injection of productive zakat capital for the second phase is still the same as the distribution of productive zakat funds in the first phase, which has received assistance has another obligation to return the funds with the system as in the first stage interest. In the final stage, BAZNAS Gorontalo city will continue to control and continuously evaluate the business development of mustahik and provide a strengthening injection of productive zakat funds for the third stage amounting to Rp. 1,000,000 (One million rupiah). (Zakaria, 2018) The strengthening process will continue as said by the Chairman of BAZNAS Gorontalo City until finally, the target of this program delivers mustahik to muzakki. (Djafar, 2018)

The above facts, both quantitative and qualitative, indicate the implications of the maximum efforts made by BAZNAS Gorontalo through the utilization of productive zakat to improve the welfare of the poor. This indication sees in the movement of the economic value of zakat in trade efforts despite the small scale of the perpetrators of poor categorized communities. There is a value to the financial benefits that citizens get in transactions that happen every day, and their value can at least help cover their daily needs.

\section{Consumptive Zakat Distribution Model}

Since confirmed by the Mayor of Gorontalo, BAZNAS Gorontalo city routinely organizes compensation to the dhu'afa. The compensation is rice, sugar, tea, and some money given to more than 1000 poor people spread across 50 villages in Gorontalo City. Chairman of BAZNAS Gorontalo City, Ramly Djafar, stated that this consumptive compensation is programmed at least once in six months to the poor in Gorontalo city (Djafar, 2018). Since its establishment until now, BAZNAS Gorontalo City has touched the poor through the dhua'fa compensation program as many as 6 (six) times in the last three years. Data support as administrative evidence of the distribution of consumptive zakat has been channeled BAZNAS Gorontalo city for the poor. The author needs to explain only one sub-district, namely The South City Subdistrict consisting of five villages.

To find out the extent of zakat management by BAZNAS Gorontalo city in its alignment with the welfare of the poor, the following authors will show the development of consumptive zakat fund distribution within three years from 2017 to 2019 . 
Table. 4 Consumptive compensation for the poor in 2017

\begin{tabular}{|c|c|l|c|}
\hline 1 & 11 Aug 17 & Compensation of the Poor & $56,340,000$ \\
\hline 2 & 29 Sep 17 & Compensation of 15 Poor People & 750,000 \\
\hline 3 & 08 Sep 17 & Zakat Ashnaf Mu'allaf Compensation in 2019 (Poor People) & $69,175,000$ \\
\hline 4 & 17 Sep 17 & Compensation of fasting program of difficult people & $1,500,000$ \\
\hline \multicolumn{2}{|c|}{ Total compensation } & $\mathbf{1 2 7 , 7 6 5 , 0 0 0}$ \\
\hline
\end{tabular}

Source: Badan Amil Zakat (BAZNAS) Gorontalo Financial Management Department BAZNAS which has been processed by the author.

Table. 5 Consumptive Compensation for the poor in 2018

\begin{tabular}{|c|c|l|c|}
\hline 1 & 04 Jan 18 & Poor Student Compensation Fund & $7,800,000$ \\
\hline 2 & 09 Mar 18 & Dana Korban Kebakaran Rumah Tinggal & $1,500,000$ \\
\hline 3 & 18 Aug 18 & Poor Student Compensation Fund & $105,170,000$ \\
\hline 4 & 15 Okt 18 & Poor Student Compensation Fund & $20,000,000$ \\
\hline 5 & 15 Okt 18 & Compensation Fund for Poor Flood Victims & $45,650,000$ \\
\hline 6 & 24 Sep 18 & $\begin{array}{l}\text { Compensation Fund for Orphans \& Displaced Children } \\
\text { (Poor People) }\end{array}$ & $50,725,000$ \\
\hline \multicolumn{2}{|r|}{ Total compensation of the poor } & $\mathbf{2 3 0 , 8 4 5 , 0 0 0}$ \\
\hline
\end{tabular}

Source: Badan Amil Zakat (BAZNAS) Gorontalo Financial Management Department BAZNAS which has been processed by the author.

Table. 6 Consumptive Compensation for the poor in 2019

\begin{tabular}{|c|c|l|r|}
\hline 1 & 21 Jan 19 & Poor Student Compensation Fund & $7,800,000$ \\
\hline 2 & 11 Jul 19 & Fund phase I Compensation for the Poor & $33,128,000$ \\
\hline 3 & 15 Aug 19 & Fund phase II Compensation for the Poor & $98,079,000$ \\
\hline 4 & 14 Sep19 & Laundry Compensation Fund, Poor people & $68,300,000$ \\
\hline 5 & $20-$ Sep-19 & Donations to Asima Polontalo & 500,000 \\
\hline 6 & $20-$ Sep-19 & Donations of the Poor & $20,000,000$ \\
\hline 7 & $13-$ Oct-19 & Fund for Iftar with the Poor & $28,760,000$ \\
\hline \multicolumn{2}{r}{ Total compensation of the poor } & $\mathbf{2 5 6 , 5 6 7 , 0 0 0}$ \\
\hline
\end{tabular}

Source: Badan Amil Zakat (BAZNAS) Gorontalo Financial Management Department BAZNAS which has been processed by the author.

Based on the results of the data conducted by the author presented in the form of the table above, it appears that the development every year seems to increase for the distribution of zakat funds that are consumptive. In 2017 zakat funds distributed consumptively to the poor amounted to Rp. 127,765,000 (One hundred twentyseven million seven hundred sixty-five thousand rupiahs). In 2018 increased more than 100\% to Rp. 230,845,000 (Two hundred thirty million eight hundred and forty-five thousand rupiahs). Similarly, in 2019 quantitatively increased to Rp. 256,567,000 (Two hundred fifty-six million five hundred sixty-seven thousand rupiahs).

The significance of good zakat management conducted by the National Zakat Agency (BAZNAS) Gorontalo city by distributing consumptive zakat enjoyed almost all poor citizens in Gorontalo city. Although it must be recognized that the dimension of welfare is not permanent rather than the distribution of zakat channeled through the utilization of productive zakat. But it must be recognized factually very rarely the poor people of Gorontalo city en masse at the same time and routinely six months once get direct compensation in addition to what has been done BAZNAS Gorontalo City.

In addition, the implications of zakat management in BAZNAS Gorontalo city on improving the welfare of the poor can be seen in the following program:

\subsection{Cooperation for ZIS Management}

Cooperation means activities or efforts carried out by several people (institutions, governments) to achieve common goals. In simple terms, cooperation describes that the person or institution in achieving its goals does not work alone but involves other people or parties so that the hopes and objectives get the better results together. The management of zakat in BAZNAS Gorontalo city becomes essential to have cooperated with various parties, 
especially institutions that concentrate on financial management.

BAZNAS pioneered cooperation with existing banks to collect ZIS through existing banks, and there are now two sharia banks that cooperate with BAZNAS in the distribution of ZIS. Banks that have cooperated with BAZNAS Gorontalo city are Bank Syariah Mandiri and Bank Muamalat Indonesia and Bank Sulut. This financial institution, in addition to being the center of storage of zakat funds derived from civil servants zakat funds from various agencies and government agencies, also as an effort to facilitate other muzakki in channeling zakat to the account BAZNAS Gorontalo city to deposit it to the Bank directly. Thus, storing zakat funds is more controlled and easily accessible by all stakeholders, and transparently accountability can be accounted for. The implication of this management profession is the increasing trust of muzakki in the existence of BAZNAS as a trusting and professional zakat institution, for then the hope of increasing public trust in distributing zakat to BAZNAS Gorontalo City is possible.

\subsection{BAZNAS Cares for Flood Victims}

Flood problems tend to increase from year to year mainly due to changes in flood character and the rapid development of various human activities in flood-prone plains. Flood disasters that occur will have a negative and wrong impact on an area where the community suffers an enormous loss materially. (Sudamara., dkk, 2019)

Gorontalo city has become a subscription to flooding from the overflow of Bolango river and Bone River, which is often the trigger for puddles experienced by the community when it rains for days. This condition hinders the citizens in meeting the needs of life. Please do not make a living, sometimes the kitchen where cooking cannot be used because it is submerged in water. This is a concern baznas Gorontalo city by opening a public kitchen for the elimination and distribution of ready meals to flood victims, especially the underprivileged. The initiation of this program can be carried out due to the sharpness of management of baznas management in optimizing zakat funds effectively and efficiently while making revisions to the program proportionally with consideration of the emergency needs (dharuri) of the poor.

\subsection{BAZNAS Creates Flood Containment Embankment}

Floods and inundations are an annual problem and significantly impact people's social, economic, and environmental conditions. Flooding is one of the most frequent disasters in the world. Floods are ranked 6th in natural disasters based on the number of incidents and the number of victims (United Nations International Strategy for Disaster Reduction /UNISDR). One of the countries that often hit by floods in Indonesia ranks 6th out of 162 countries with 1,101,507 people affected. (Kemenkokesra, 2014). Flooding causes many health problems, such as the onset of various diseases (ISPA, diarrhea, skin diseases, leptospirosis, and others). Cases of disease that occur at the time of disaster and often increase significantly even cause extraordinary events (KLB) until death. (Mirahesti, 2014).

As a contribution to flood management that affects the onset of various problems, through optimization of the use of zakat for the life mustahik, another breakthrough made BAZNAS Gorontalo city is the manufacture of embankment along 60 meters with a height of 1.5 meters in the Village Donggala District of South City Gorontalo City. Initially, BAZNAS will provide repair assistance for residents whose homes were damaged by flooding some time ago, but the homeowners and residents requested that the repair assistance of damaged houses be diverted to the manufacture of flood containment embankments. Therefore, they agreed to ask BAZNAS to divert the home improvement assistance fund into funds to construct flood containment embankments. So that a sense of security and comfort in life will be created and they can try and make a living even if it is for the family calmly.

\subsection{Livable House (MAHAYANI) BAZNAS Flagship Program}

Housing development policy is an instrument of the government to intervene in regional development (Kawer, 2018). Because one of the basic needs challenging to meet by the poor is decent housing for families. Uninhabitable houses are uninhabitable dwellings or dwellings caused by insufficient requirements, both technical and non-technical, as a home to live in.

In response to such conditions, BAZNAS Gorontalo city launched a habitable building house whose entire cost is borne by BAZNAS. Residents include a certificate from Lurah that the land occupied is owned and has no problems. It is then submitted to BAZNAS Gorontalo City, after which BAZNAS will lower the team to see and check its feasibility. If the verification result is declared feasible, then BAZNAS will build a livable house until one hundred percent is completed. Until now, the low-grade community that has been touched by the assistance of livable houses (MAHAYANI) has numbered 16 families with 16 MAHAYANI buildings.

\subsection{Scholarships for Outstanding Children}

Scholarships are an effort to help people who attend education through school or college fulfill and complete the educational process to achieve graduation. The assistance is usually in the form of funds to support the cost of 
education during the students' education. Scholarships can also be financing that is not sourced from self-funding, either from individuals for the learning process at the university or educational institutions outside or within the country. Scholarships are part of efforts to improve equality and provide learning opportunities for students who are experiencing economic difficulties, encourage and maintain the spirit of learning students so that they can complete their education on time, encourage the improvement of academic achievement, thus spurring the quality of education and strengthening human resources.

Even regulatory Law No. 20 of 2003 on the National Education System mandates in Chapter V article 12 Paragraph 1c "that every student in every educational unit (including students) is entitled to a scholarship for the outstanding and his parents cannot afford his education." On the other hand, it is undeniable that youth and youth are continuing the continuity of da'wah and development in a country. The role of the younger generation is crucial in determining the success of da'wah in the future. Therefore, BAZNAS Gorontalo city is committed to giving appreciation and encouragement to the younger generation, especially young men and young Muslims, to hone themselves and carve out achievements as a provision in facing the challenges ahead. One of the appreciations is given in the form of scholarships for students and students who excel in selecting children with competition (PPIB) held in Gorontalo City. The scholarship is in the form of tuition and school fees for one year.

\subsection{Amaliah Ramadhan Movement}

BAZNAZ Management of Gorontalo City every Ramadan Formed the Implementation Team of Amaliah Ramadhan Movement through BAZNAS infrastructure. This movement conducts Ramadan activities in each village to escort, guide and lead worshipers in order to maximize the month of Ramadan as the month of Worship. BAZNAS Gorontalo city has also selected outstanding Imams assigned specifically to become imams of rawatib prayers and tarawih circumcision prayers in several mosques in Gorontalo city. This movement doing to make BAZNAS not only take care, manage and make the poor prosper financially but a group of BAZNAS optimizing programs oriented towards improving spiritual welfare.

Therefore, various programs that have been launched by BAZNAS Gorontalo city have attracted the attention of many parties. Some areas that conduct comparative studies of Zakat management in Gorontalo City - started by North Bolaang Mongondow (BOLMUT) Local Government, Pohuwato, North Gorontalo, and others. Also, BAZNAS Gorontalo city has become the research object of students from various universities in Gorontalo City, both undergraduate and post-graduate programs. Some activities carried out by the Ministry of Religious Affairs of Gorontalo Province involve BAZNAS Gorontalo City, especially in providing ZIS management materials. This trust is born from the increasing existence of zakat management in BAZNAS Gorontalo city, which increasingly shows significant management optimization than to affect the improvement of the welfare of the poor.

\section{Conclusion}

Zakat is a religious obligation to give some wealth to those in need, has played an essential role in providing social assistance for centuries. Zakat funds are increasingly institutionalized and part of many countries' social protection systems, providing cash, food, health care, and education to the poor. This paper discusses the management of the Zakat Fund in Gorontalo city. Many messages can be retrieved from this case study:

The implications of zakat management in BAZNAS Gorontalo city in improving the welfare of the poor are seen in various innovations of the rolled-out program. Since its establishment now, BAZNAS Gorontalo City has launched a program oriented towards improving the welfare of the poor.

Innovation of programs with the initiative of impartiality in the empowerment of welfare of the poor manifested in the multi-program rolled out, empowerment of the poor through the utilization of productive zakat distribution, distribution of consumptive zakat, a synergy of zakat management with professional financial institutions, caring for disaster victims, the construction of Livable Houses (MAHAYANI), scholarships for outstanding children and the movement of amaliah Ramadhan.

\section{References}

Bilo, C. and Machado, A.C. (2020), "The role of Zakat in the provision of social protection: A comparison between Jordan and Sudan", International Journal of Sociology and Social Policy, Vol. 40 No. 3/4, pp. 236248. https://doi.org/10.1108/IJSSP-11-2018-0218

Ben Jedidia, K. and Guerbouj, K. (2020), "Effects of zakat on the economic growth in selected Islamic countries: empirical evidence", International Journal of Development Issues, Vol. 20 No. 1, pp. 126-142. https://doi.org/10.1108/IJDI-05-2020-0100

Dean, H. and Khan, Z. (1997), "Muslim perspectives on welfare”, Journal of Social Policy, Vol. 26 No. 2, pp. 193-209.

Djafar, Ramli. Chairman of BAZNAS Gorontalo City, interview by author in Gorontalo City, July 25, 2018.

Departemen Kebudayaan dan Pendidikan, Kamus Besar Bahasa Indonesia, (Jakarta: Balai Pustaka, 2005), h. 753 
Enov Sayu Mimanggar Mirahesti. (2014), Evaluasi Perencanaan Prabencana Banjir Bengawan Solo Kabupaten Bojonegoro. 10.20473/jbe. v4i2.2016.262

Hasan, S. (2015), "Islam, property and philanthropy: ethical and philosophical foundations and cultural influences", in Hasan, S. (Ed.), Human Security and Philanthropy: Islamic Perspectives and Muslim Majority Country Practices, Springer, New York, NY, pp. 51-74.

Hasan, S. (2006), "Muslim Philanthropy And Social Security: Prospects, Practices, And Pitfalls", 6th ISTR Biennial Conference, Bangkok, pp. 9-12.

Hassan, M.K. (2010), "An integrated poverty alleviation model combining Zakat, Awqaf and micro-finance”, Seventh International Conference-The Tawhidic Epistemology: Zakat and Waqf Economy, Bangi, pp. 261281

Kaaba, Hariyati. (2018), Zakat Organizer in Gorontalo City Ministry, interview by author in Gorontalo City.

Kusumadinata, Ali Alamsyah. (2019), 'Pemanfaatan Media Informasi Dalam Program Rumah Tidak Layak Huni (Rtlh)', Qardhul Hasan: Media Pengabdian Kepada Masyarakat. <https://oi.org/10.30997/qh.v4i2.1261>

Katili, Lukman. Academician/Religious Figure, interview by author in Gorontalo City, October 20, 2018.

Moeloeng, Lexy J. (2012), Metodologi Pendidikan dengan Pendekatan Baru. (Bandung: PT. Remaja Roesdakarya)

Mubarokah, Isro'iyatul, Irfan Syauqi Beik, Tony Irawan. (2017), Dampak Zakat terhadap Kemiskinan dan Kesejahteraan Mustahik (Kasus: BAZNAS Provinsi Jawa Tengah) Jurnal Al-Muzara'ah Vol.5, No.1. (ISSN p:2337-6333; e:2355-4363.

Mustofa. (August 23, 2018), Academician/Sharia Economics Activist/Lecturer Fak. Shari'ah IAIN Sultan Amai Gorontalo, interview by author in Gorontalo City.

Ngou, Sabara K. (August 21, 2018), Head of Gorontalo City Ministry of Religious Affairs Office, interview by author in Gorontalo City,

Sri Fadilah, Rini Lesatari dan Yuni Rosdiana, Organisasi Pengelola Zakat (OPZ) Deskripsi Pengelolaan Zakat dari Aspek Lembaga Zakat, Universitas Islam Bandung Vol.18 No.2 September 2017 PP 148-163 file://C:/Users/Asus/AppData/Local/Temp/ 3085-9450-2-PB.pdf

Orthinus Ferdinando Samfar Kawer, M. Baiquni, Yeremias T. Keban, Agustinus Subarsono. (2018), 'Implementasi Kebijakan Pembangunan Rumah Layak Huni Dengan Pendekatan Hibrida Di Kabupaten Supiori Provinsi Papua, Jurnal Sosio Humaniora. vol. 2. 0i3.18489.

Pedju, Raman. (July 27, 2018), Manager of BAZNAS Gorontalo City, interview by the author in Gorontalo City.

Rahmat, R.S. and Nurzaman, M.S. (2019), "Assesment of zakat distribution: A case study on zakat community development in Bringinsari village, Sukorejo district, Kendal", International Journal of Islamic and Middle Eastern Finance and Management, Vol. 12 No. 5, pp. 743-766. https://doi.org/10.1108/IMEFM-12-20180412

Sudamara, Yoktan, Bonny F Sompie, and Robert J M Mandagi, 'Optimasi Penanggulangan Bencana Banjir di Kota Manado Dengan Detode AHP (Analytical Hierarchy Process)', Media Engineering, 2012.

Sugandi. (2007), Model Penanggulangan Banjir, Ejournal.upi.edu/index.php/gea/artcle/view/1709

Widiastuti, T., Cahyono, E.F., Zulaikha, S., Mawardi, I. and Al Mustofa, M.U. (2021), "Optimizing zakat governance in East Java using analytical network process (ANP): the role of zakat technology (ZakaTech)", Journal of Islamic Accounting and Business Research, Vol. ahead-of-print No. ahead-of-print. https://doi.org/10.1108/JIABR-09-2020-0307

Winarno, Bambang. (2018), 'Evaluasi Program Penyediaan Rumah Layak Huni Bagi Masyarakat Miskin Di Kabupaten Belitung', Jurnal Pengembangan Kota, <https://doi.org/ 10.14710/jpk.6.1.66-74>.

Zakaria, Saleha. (August 29, 2018), Head of Development Section concurrently Head of Secretariat of BAZNAS Gorontalo City, interview by author in Gorontalo City. 